Research paper

\title{
Composition and growth of sorghum biomass genotypes for ethanol production
}

\author{
Luciana Gomes Fonseca de Almeida ${ }^{\mathrm{a}, *}$, Rafael Augusto da Costa Parrella ${ }^{\mathrm{b}, * *}$, \\ Maria Lúcia Ferreira Simeone ${ }^{\mathrm{b}, * * * *}$, Pedro César de Oliveira Ribeiro ${ }^{\mathrm{d}}$, \\ Alexandre Soares dos Santos ${ }^{\mathrm{a}}$, Alexandre Sylvio Vieira da $\operatorname{Costa}^{\mathrm{c}}$, Amanda Gonçalves Guimarães ${ }^{\mathrm{a}}$, \\ Robert Eugene Schaffert ${ }^{\mathrm{b}}$
}

${ }^{a}$ Federal University of Jequitinhonha and Mucuri Valleys, Campus JK, BR-367, 5000, Diamantina, MG, 39100-000, Brazil

${ }^{\mathrm{b}}$ Embrapa Milho e Sorgo, Rod MG 424, Sete Lagoas, MG, 35701-970, Brazil

${ }^{\mathrm{c}}$ Federal University of Jequitinhonha and Mucuri Valleys, Campus Mucuri, Teófilo Otoni, MG, Brazil

${ }^{\mathrm{d}}$ Federal University of Viçosa, Viçosa, MG, 36570-900, Brazil

\section{A R T I C L E I N F O}

\section{Keywords:}

Sorghum bicolor

Chemical composition

Adaptability

brown midrib

Lignocellulosic ethanol

\begin{abstract}
A B S T R A C T
Sorghum bicolor (L.) (Moench), which stands out for dry matter yield per hectare, has been considered as potential raw material for biofuels and electricity generation. It has a production cycle of six months, possibility of mechanization of cultivation and harvest and good adaptation to most regions of Brazil. Sorghum genotypes were evaluated for agronomic potential and chemical composition favorable to the production of second-generation ethanol. Three brown midrib (bmr) sorghum mutant hybrids were compared to three conventional hybrids. The $b m r$ sorghum mutant hybrids are associated with reduced lignin content, making these genotypes more promising to the enzymatic conversion processes of the biomass. Sorghum biomass showed a high potential in terms of biomass production, with an average dry matter yield of $26.57 \mathrm{Mg} \mathrm{ha}^{-1}$. Brown midrib sorghum hybrids showed significantly lower lignin contents than conventional hybrids and demonstrated the potential for cellulosic ethanol production.
\end{abstract}

\section{Introduction}

The need to diversify the world energy matrix and to increase the share of renewable sources has promoted the search for environmentally and economically sustainable technologies [1,2]. In addition, there is strong international pressure to reconcile future energy and fuel demands with the reduction of greenhouse gas emissions such as $\mathrm{CO}_{2}$ [3]. In this scenario, biofuels were raised to the status of technological alternative readily available to reduce fossil liquid fuel consumption. The United States of America is now the world's largest producer of biofuels, followed by Brazil [4,5]. Among biofuels, Brazilian ethanol stands out as an advanced fuel capable of boosting the low carbon market and the national industry, as it is environmentally sustainable for the substitution of fossil fuels. Brazil, although it has an expressive ethanol production capacity [6], being the largest producer of this biofuel in South America [7], presents itself with the challenge of diversifying the raw materials for the production of biofuels, being still dependent on soyabean (Glycine max L.) and sugarcane (Saccharum officinarum L.). Currently, biomass sorghum (Sorghum bicolor (L.) Moench) has become a promising crop for lignocellulosic ethanol production [8,9]. Sorghum is a C4 plant, photoperiod sensitive, characteristic of short day and with high photosynthetic rates. In order to reach a good development most cultivars need temperatures above $21^{\circ} \mathrm{C}$. Sorghum has a higher tolerance to soil water deficit and excess moisture than most other cereals and can be grown in a wide range of soil conditions [10]. Besides, it has the advantage of having a short growth cycle (150-180 days), being propagated by seeds and having a fully mechanized production $[11,12]$.

As a crop that is more resistant to water stress, sorghum has been used as a second harvest [13] where the climate is drier, including the

\footnotetext{
* Corresponding author.

** Corresponding author.

*** Corresponding author.

E-mail addresses: luagro2005@yahoo.com.br (L.G.F.d. Almeida), rafael.parrella@embrapa.br (R.A.d.C. Parrella), marialucia.simeone@embrapa.br (M.L.F. Simeone), pedroc.ribeiro14@gmail.com (P.C.d.O. Ribeiro), alexandre.soares@ufvjm.edu.br (A.S. dos Santos), alexandre.costa@ufvjm.edu.br (A.S.V. da Costa), amandagguimarães@yahoo.com.br (A.G. Guimarães), robert.schaffert@embrapa.br (R.E. Schaffert).
} 
possibility of another annual harvest, two harvests per year. Moreover, it also has the advantage of being able to be cultivated in the during the intercrop period sugarcane, increasing the number of days worked per year in the distilleries, mainly with the supply of raw material in the months of March and April, raising the economic viability of the ethanol [14]. It is also considered that sorghum biomass is a renewable and low-cost source of energy [15], which can be used to promote the competitiveness of the industry and contribute to the strategy of a green economy.

Conventionally, sorghum types are used both for forage production, for sugars and fiber production [16]. Among the sorghum cultivars, sorghum biomass emerges as an alternative for the supply of raw material for the bioenergy market, both in the form of liquid biofuel, with the production of second-generation ethanol, and in the generation of energy [17] by direct biomass burning.

In addition to the aforementioned advantages, sorghum biomass also presents a chemical composition considered initially adequate, since aiming at the production of second-generation ethanol, in addition to the need for a high productivity of dry biomass, the raw material used must present favorable chemical composition to the processes used to obtain bioethanol. Therefore, the chemical characteristics of biomass have a direct influence on the energy conversion process [18], and the production of lignocellulosic biofuels involves the depolymerization of polysaccharides from the cell wall, being cellulose and hemicellulose [20].

Thus, biomass of sorghum, with high adaptability, presents high fiber content, besides significant amounts of fermentable sugars, which can be exploited in large scale [21]. However, genotypes of sorghum have a great variation in relation to the content of the cell wall, mainly in relation to lignin [19]. Genes called $b m r$, which confer the phenotype of brown midrib to the plant, are responsible for expressing the low lignin contents $[22,57,58]$.

In sorghum, bmr mutant plants were obtained through chemical induction with diethyl sulfate [23]. Several studies have demonstrated that genes responsible for the bmr mutation act by reducing the activity of enzymes involved in the lignin biosynthesis process [24-26]. The bmr- 6 allele causes reduced activity of the enzyme cinamil álcool desidrogenase (CAD), while bmr-12 e bmr-18 reduced activity of the enzyme O-metiltransferase (OMT) in the lignin synthesis of the sorghum plant $[26-28,59,60]$.

Therefore, mutant genotypes of biomass sorghum with low lignin bmr (brown midrib) content and photoperiod sensitive, differing in quality and quantity in relation to the composition of the cell wall and digestibility of the vegetal fiber when compared to the regular materials $[29,30]$, are interesting for the production of second generation ethanol. In the production of cellulosic ethanol, it is necessary to deconstruct the plant cell wall by means of chemical and/or physical treatments, and less recalcitrant materials optimize the pretreatment steps for the depolymerization of the lignocellulosic biomass $[19,28,61,67]$. The objective of this work was to evaluate the agronomic performance and chemical composition of six hybrids of sorghum biomass, three sorghum genotypes bmr- 6 and three conventional, in two localities of the State of Minas Gerais, for future analyzes of cellulosic ethanol production.

\section{Material and methods}

\subsection{Plant material}

Six biomass sorghum hybrids, all photoperiod sensitive, were developed by the Embrapa Maize and Sorghum breeding program, five of which were experimental lines (201556B001, 201556B002, 201556B003, CMSXS7027 and CMSXS7016), and one commercial (BRS 716), of which the first three are experimental bmr hybrids.

\subsection{Experimental environments}

Sorghum biomass planting was conducted in two distinct regions of the State of Minas Gerais, Brazil, in the agricultural year 2015/2016. One of the regions was the city of Sete Lagoas, at the experimental area of Embrapa Maize and Sorghum ( $-19^{\circ} 28$ 'S and $\left.44^{\circ} 15^{\prime} \mathrm{W}\right)$, at $732 \mathrm{~m}$ altitude. Alto Vale do Jequitinhonha was the other region, with trials conducted at the Rio Manso Experimental Farm, of the Federal University of the Jequitinhonha and Mucuri Valleys $\left(18^{\circ} 04^{\prime} \mathrm{S}\right.$ and $43^{\circ} 28^{\prime} \mathrm{W}$ ), located in Couto de Magalhães de Minas city, at $733 \mathrm{~m}$ altitude. The climate of the two regions, according to classification of Köppen, is Aw type, with dry season from May to October and humid from November to April. The accumulated rainfall during the period of sorghum growth was $799.1 \mathrm{~mm}$ in Sete Lagoas and $446.5 \mathrm{~mm}$ in Couto de Magalhães de Minas. The maximum and minimum temperatures were between $33^{\circ} \mathrm{C}$ and $18{ }^{\circ} \mathrm{C}$, respectively. The soils of both crops are classified as dystrophic Yellow Red Latosol, clay texture.

In Sete Lagoas, the cultivation of sorghum occurred in the period from $11 / 26 / 2015$ to $05 / 17 / 2016$, totaling 173 days after planting (DAP). In Couto de Magalhães de Minas, the planting was carried out on $10 / 12 / 2015$, and the crops continued in the following order, continued on sequential days: 201556B002 and 201556B003 125 DAP; 201556B001 and CMSXS 7027138 DAP; BRS 716 and CMSXS 7016150 DAP.

In both environments, a $6 \times 2 \times 3$ randomized block design (CBD) was used, consisting of six treatment with two rows of $5 \mathrm{~m}$ each, spaced $0.7 \mathrm{~m}$ apart. Three replicates were used for each treatment. The material was manually sown, and at 21 days after emergence, thinning was performed for 40 plants per row, providing a stand with approximately 140,000 plants per hectare ( 8 plants per linear meter). Planting was applied at a dose of $400 \mathrm{~kg} \mathrm{ha}^{-1}$ of NPK (08-28-16) and cover fertilization with $80 \mathrm{~kg} \mathrm{ha}^{-1}$ of $\mathrm{N}$, when the plants were at the V4-V6 growth stage.

The variables evaluated in the field were: i) plant height $(\mathrm{PH})$ : average height of the plants representative of the useful area of the plot, considering the distance from the soil surface to the apex of the panicle, measured in meters; ii) fresh biomass yield (FBY): was determined based on the weight of total plants in each plot, converted result for t.ha ${ }^{-1}$; (iii) dry biomass yield (DBY): product by percentage of dry biomass yield, expressed as $\mathrm{t} \mathrm{ha}^{-1}$; (iv) dry biomass (DB): in order to determine dry weight, stems, leaves and panicles were placed into paper bags and dried at $65^{\circ} \mathrm{C}$ for $72 \mathrm{~h}$. Samples were then grinded at $2 \mathrm{~mm}$ mash and prepared for chemical analysis.

The contents of acid detergent fiber (ADF), neutral detergent fiber (NDF) and lignin (ADL) were determined according to methodologies proposed by Ref. [31]. The cellulose content was calculated from the difference between the content of FDA and lignin; and the hemicellulose content was calculated from the difference between the NDF and the ADF content.

\subsection{Statistical analysis}

The analysis of variance for each environment was carried out in isolation to verify the existence of equal residual variances by the relation between the largest and the smallest mean square of the residue of the environments in all the characteristics [32]. Then, the analysis of variance were performed according to the statistical model: $Y_{i j m}=m+B / A_{j k}+G_{i}+A_{j}+G_{i j}+E_{i j k}$, where $Y_{i j k}=$ observation of genotype $\mathrm{i}$ in the environment $\mathrm{j}$ and in block $\mathrm{k} ; \mathrm{m}=$ general average; $G_{i}=$ effect of the $i$-th genotype; $A_{j}=$ effect of the jth environment; $\mathrm{GA}_{\mathrm{ij}}=$ effect of the ith genotype interaction in the jth environment; $\mathrm{B} /$ $A_{j k}=$ effect of the kth block within the jth environment; $E_{i j} k_{m}=$ mean experimental random error associated with the observation $Y_{i j l m}$.

A comparison of means was then performed using the Scott Knott test [33]. Subsequently, Person's correlation was performed between the presented characteristics. Data were analyzed by using the Genes 
Table 1

Joint variance analysis of six hybrids of biomass sorghum. Sete Lagoas and Couto de Magalhães de Minas, Minas Gerais, harvest $2015 / 2016$.

\begin{tabular}{|c|c|c|c|c|c|c|c|c|c|}
\hline \multirow[t]{2}{*}{ FV } & \multirow[t]{2}{*}{ Df } & \multicolumn{8}{|c|}{ Mean Square } \\
\hline & & $\mathrm{PH}$ & FBY & DBY & NDF & $\mathrm{ADF}$ & Cellulose & Hemicellulose & Lignin \\
\hline Block/Env. & 4 & 0.56 & 153.55917 & 39.62532 & 10.18968 & 10.70813 & 3.13812 & 1.2884 & 2.61997 \\
\hline Hybrids & 5 & $0.47^{\mathrm{NS}}$ & $1061.37^{* *}$ & $259.36^{* *}$ & $25.70 \mathrm{~ns}$ & $29.47 \mathrm{~ns}$ & $10.07 \mathrm{~ns}$ & $9.88^{*}$ & $9.09 *$ \\
\hline Environment & 1 & $5.65^{*}$ & $602.78 \mathrm{~ns}$ & $302.17 \mathrm{~ns}$ & $174.36^{* * *}$ & $169.13^{* *}$ & $65.49 * *$ & $0.04 \mathrm{~ns}$ & $24.13^{* *}$ \\
\hline Hyb./Env. & 5 & $0.29^{\mathrm{NS}}$ & $38.62 \mathrm{~ns}$ & $10.80 \mathrm{~ns}$ & $18.57 \mathrm{~ns}$ & $11.19 \mathrm{~ns}$ & $5.05 \mathrm{~ns}$ & $1.56 \mathrm{~ns}$ & $1.26 \mathrm{~ns}$ \\
\hline Residue & 20 & 0.21 & 92.51 & 16.47 & 8.19 & 6.25 & 4.42 & 1.74 & 0.51 \\
\hline \multirow[t]{2}{*}{ Mean } & & 4.17 & 80.60 & 26.57 & 70.45 & 43.40 & 37.12 & 27.05 & 6.29 \\
\hline & & 11.03 & 11.93 & 15.28 & 4.06 & 5.76 & 5.66 & 4.88 & 11.39 \\
\hline
\end{tabular}

Híb./Env. = Environment genotype interaction; FV = Source of variation; Df = Degrees of freedom; $\mathrm{PH}=$ height of plants (m); FBY = fresh biomass yield (Mg $\left.\mathrm{ha}^{-1}\right)$; DBY $=$ dry biomass yield $\left(\mathrm{Mg} \mathrm{ha}^{-1}\right)$; cellulose, hemicellulose and lignin (\%).

ns, **, * = non significant, significant $\mathrm{p}<0.01$ and $\mathrm{p}<0.05$, respectively by the $\mathrm{F}$ test.

software program [34].

\section{Results and discussion}

Initially the analysis of individual variance of each environment was obtained and the homogeneity of the residual variances in all the characters was verified. The ratio between the largest and the smallest mean square of the residue obtained in both environments was less than 7 (FBY $=1.01$ and hemicellulose $=1.79)$, which made possible the joint analysis [32]. The coefficients of variation presented low values for all evaluated characters $(\mathrm{FBY}=11.93$ and $\mathrm{NDF}=4.06)$. Note that values of coefficient of variation below $20 \%$ determine good experimental precision [32]. A significant variance ( $\mathrm{p} \leq 0.05)$ was observed for the FBY, DBY, hemicellulose and lignin, for the hybrid variation source (Table 1). This significant effect shows the existence of genetic variability among the evaluated genotypes, which will allow the selection of superior materials in order to succeed in the selection process [35]. There was a significant effect $(p \leq 0.05)$ between environments for the PH, NDF, ADF, cellulose and lignin contents, showing the existence of environmental differences among the evaluated sites. The non-occurrence of interaction between hybrids and environments for all evaluated characters was observed, showing a coincident behavior of the hybrids in the evaluated environments (Table 1). Table 2 shows the mean values of the evaluated characteristics of the six sorghum biomass genotypes, grouped by the Scott and Knott test at $5 \%$ probability.

Mean values for FBY ranged from $99.86 \mathrm{Mg} \mathrm{ha}^{-1}$ to $67.05 \mathrm{Mg} \mathrm{ha}^{-1}$ (Table 2). This result corroborates the study of [36], when evaluating 16 genotypes of sorghum biomass, which obtained averages of $124.28 \mathrm{Mg} \mathrm{ha}^{-1}$ at $69.19 \mathrm{Mg} \mathrm{ha}^{-1}$. It is noted that the materials CMSXS7027, CMSXS7016 and BRS716 were grown in both experiments and resulted in approximate means. Castro et al. [36] found 93.87 $\mathrm{Mg} \mathrm{ha}^{-1}, 101.73 \mathrm{Mg} \mathrm{ha}^{-1}$ and $82.97 \mathrm{Mg} \mathrm{ha}^{-1}$, respectively, in the cultivation carried out near Lavras, - State of Minas Gerais, Brazil. Data obtained by Ref. [37] show that biomass sorghum has the potential to produce up to $102.22 \mathrm{tha}^{-1}$ of FBY. The higher biomass accumulation in sorghum hybrids, according to Ref. [38], can be explained by the longer vegetative period (photoperiod sensitivity), higher leaf area index, greater interception and efficient use of radiation (plant C4).

Regarding dry biomass yield (DBY), mean values ranged from $35.59 \mathrm{Mg} \mathrm{ha}^{-1}$ to $20.64 \mathrm{Mg} \mathrm{ha}^{-1}$. The results found among hybrids CMSXS7016 and BRS716 were significant, and they obtained the best performances, reaching a dry mass yield of $34.05 \mathrm{Mgha}^{-1}$ and $35.59 \mathrm{Mg} \mathrm{ha}^{-1}$, respectively. Castro et al. [36] obtained similar results for the same materials, finding $37 \mathrm{Mg} \mathrm{ha}^{-1}$ and $36 \mathrm{Mg} \mathrm{ha}^{-1}$, respectively. These results corroborate the findings of [39], in which they obtained averages of $37.95 \mathrm{Mg} \mathrm{ha}^{-1}$ at $27.95 \mathrm{Mg} \mathrm{ha}^{-1}$, when cultivating near Janaúba and Sete Lagoas, State of Minas Gerais, Brazil, respectively.

The average dry biomass yield of sorghum biomass can reach more than $30 \mathrm{Mg} \mathrm{ha}^{-1}$, and some experimental materials from the breeding program of Embrapa Maize and Sorghum already have productivity above $50 \mathrm{Mg} \mathrm{ha}^{-1}$ dry biomass yield [40]. The DBY characteristic is one of the most important because it reflects the productivity achieved, and its significant effect allows selecting the best material to achieve greater gains in biomass. In addition, flowering is another parameter that may influence SMP. Therefore, all genotypes flowered from April, totaling approximately 120 days after planting, and, therefore, a greater vegetative cycle and consequently greater accumulation of biomass, confirming the sensitivity to the photoperiod, since from March the

Table 2

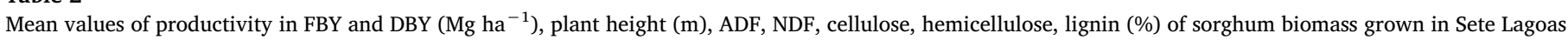
and Couto de Magalhães de Minas, in the 2015/2016 season.

\begin{tabular}{|c|c|c|c|c|c|c|c|c|}
\hline Hybrids & $\mathrm{PH}$ & FBY & DBY & $\mathrm{NDF}$ & $\mathrm{ADF}$ & Cellulose & Hemicellulose & Lignin \\
\hline 201556(B)001 & $3,84 \mathrm{a}$ & $67,05 \mathrm{~b}$ & $20,64 \mathrm{~b}$ & $72,84 \mathrm{a}$ & $43,93 \mathrm{a}$ & $38,25 \mathrm{a}$ & 28,91 a & $5,68 \mathrm{~b}$ \\
\hline 201556(B)002 & 4,09 a & $71,55 \mathrm{~b}$ & $21,18 \mathrm{~b}$ & $68,39 \mathrm{a}$ & $40,61 \mathrm{a}$ & 35,81 a & 27,77 a & $4,79 \mathrm{~b}$ \\
\hline 201556(B)003 & 3,89 a & $71,75 \mathrm{~b}$ & $23,31 \mathrm{~b}$ & $68,95 \mathrm{a}$ & $41,36 \mathrm{a}$ & 36,19 a & 27,58 a & $5,17 \mathrm{~b}$ \\
\hline CMSXS7027 & 4,55 a & $79,77 \mathrm{~b}$ & $24,60 \mathrm{~b}$ & $73,06 \mathrm{a}$ & $46,84 \mathrm{a}$ & 39,07 a & $26,45 \mathrm{~b}$ & $7,77 \mathrm{a}$ \\
\hline CMSXS7016 & 4,27 a & $93,61 \mathrm{a}$ & 34,05 a & $70,53 \mathrm{a}$ & $44,08 \mathrm{a}$ & 37,09 a & $26,22 \mathrm{~b}$ & $6,99 \mathrm{a}$ \\
\hline BRS716 & 4,39 a & 99,86 a & 35,59 a & 68,92 a & 43,57 a & $36,26 \mathrm{a}$ & $25,34 \mathrm{~b}$ & 7,31 a \\
\hline Sete Lagoas & 4,57 a & 84,69 a & 29,46 a & $72,65 \mathrm{a}$ & $45,57 \mathrm{a}$ & $38,46 \mathrm{a}$ & $27,08 \mathrm{a}$ & $7,11 \mathrm{a}$ \\
\hline Couto & $3,78 \mathrm{~b}$ & 76,51 a & 23,67 a & $68,25 \mathrm{a}$ & $41,23 \mathrm{~b}$ & 35,77 a & $27,02 \mathrm{a}$ & $5,47 \mathrm{~b}$ \\
\hline
\end{tabular}

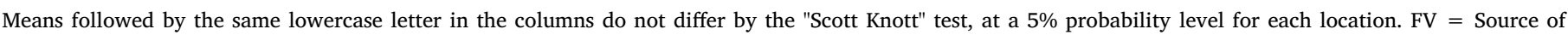

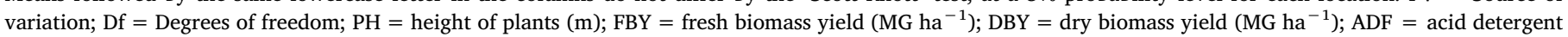
fiber; NDF $=$ neutral detergent fiber; $\mathrm{ns},{ }^{* *},{ }^{*}=$ non significant, significant $\mathrm{p}<0.01$ and $\mathrm{p} \leq 0.05$, respectively by the test $\mathrm{F}$. 
days become shorter [37]. obtained similar flowering results in a study with 25 cultivars of sorghum biomass at four locations, where the average number of flowering days ranged from 100 to 148 DAP. DBY expresses the potential of the hybrid as a high yield requirement in biomass production for conversion to cellulosic ethanol.

Among chemical constituents, related to the biomass quality, the contents obtained for NDF, ADF, cellulose, hemicellulose and lignin are expressed as percentage (\%) in relation to the dry mass at $65^{\circ} \mathrm{C}$. The mean contents of NDF and ADF ranged from $68.39 \%$ to $73.06 \%$, and $40.61 \%-46.84 \%$, respectively (Table 2). These results corroborate with that found by Ref. [36], who obtained a mean of $71 \%$ for NDF and mean content of $\mathrm{ADF}$ ranging from $38.7 \%$ to $51.9 \%$. In relation to the lignocellulosic composition of the hybrids of sorghum biomass evaluated, average contents were obtained from $35.81 \%$ to $39.07 \%$ of cellulose; $25.34 \%-28.91 \%$ hemicellulose, and $4.795-7.31 \%$ lignin, respectively (Table 2). [41], when evaluating the fiber and mineral profile of biomass sorghum cultivars, found between 40.0 and $44.4 \%$ of cellulose, $26.6-29.4 \%$ of hemicellulose, and $7.7 \%$ to $8.9 \%$ of lignin. The significant effect for the hemicellulose and lignin characters is important for decision making in the choice of material to be used in saccharification and fermentation processes, with the objective of producing second-generation ethanol, since these characteristics may influence the final yield of the biofuel. For the PH, NDF, ADF and cellulose characteristics, the hybrids did not differentiate statistically from each other, which implies that among the tested materials any hybrid can be selected that will have similar results as the others. The environment of Sete Lagoas resulted in higher average performance, compared to the city of Couto de Magalhães de Minas, for the characteristics ADF and lignin, as can be observed in Table 2. Therefore, the environmental influence in the expression of characters can be justified by several factors, such as: difference in edaphoclimatic variations between the two environments during the growing season; accumulated precipitation; temperature; severity of diseases that affect the culture, among others [42].

Cellulose and hemicellulose are the main polysaccharides of biomass, and their contents impact on the yield of the enzymatic hydrolysis and consequently on the amount of ethanol obtained. Therefore, to obtain second-generation ethanol, biomass deconstruction is necessary, with the delignification and exposure of the cellulosic fibers in order to obtain the saccharification efficiently [20]. However, lignin, which is a polyphenolic compound, interferes with the saccharification process [43], since it gets in the way of the action of the enzymes to the cellulosic complex, besides being a potential release medium of inhibitors to the fermentation process [44]. Lignin is strongly associated with cellulose as a protective barrier to external agents. Thus, during enzymatic hydrolysis, the enzymes tend to bind irreversibly to the lignin by means of hydrophobic interactions, which causes loss of activity and the requirement of a greater enzymatic charge in the process [68]. Lignin acts negatively on enzymatic hydrolysis by three main factors: competitive adsorption, chemical inhibition and steric hindrance [44,69].

In relation to the lignin character, therefore, there was a difference between the environments, a fact that can also be proven by the higher levels of ADF at this site. As reported by Ref. [20], the chemical composition of the lignocellulosic biomass can present an enormous variation according to the location of the crop, cultivars and harvest time, when carrying out an experiment with sugarcane bagasse and sorghum bagasse. Therefore, as the materials grown in Sete Lagoas remained a longer period in the field, and consequently with greater physiological development [45], so, the lignification process was favored. It is also observed that there was a difference between hybrids, with the genotypes bmr (201556B001, 201556B002, 201556B003) showing the lowest percentages of lignin. The low lignin content in the 201556B001, 201556B002 and 201556B003 hybrids (Table 2) suggest that the presence of the $b m r$ allele in these materials gives the biomass significant differences in the composition of the plant cell wall, in addition to promoting a better digestibility of the fiber.

When comparing sorghum biomass to sugarcane bagasse, the most widely studied lignocellulosic residue for the production of secondgeneration ethanol, a great advantage is observed, since on average the composition of the sugar cane bagasse is $35-45 \%$ cellulose, $26.2-35.8 \%$ hemicellulose and 11.4-25.2\% lignin [46-49] [20]. also obtained lower levels of lignin in sorghum bagasse compared to sugarcane bagasse. Therefore, high lignin contents in lignocellulosic materials increase the cost of the whole process, since besides lignin irreversibly adsorb enzymes and inhibit their action in the cellulose chains, more severe pretreatments are necessary in order to reduce the recalcitrance of the plant biomass [50,51].

The economic viability of bioethanol production on industrial scale has been shown to be a determining factor the efficiency of the pretreatment and the hydrolysis of lignocellulosic biomass [52]. The hemicellulose character showed no significant difference between the environments. However, there was a difference between cultivated hybrids, with the brown midrib hybrids (201556B001, 201556B002, 201556B003) showing the highest contents. From the perspective of using hemicellulose, significant values may represent an important factor in increasing ethanol production from five carbon sugars - pentoses (C5) and six carbon sugars - hexoses (C6) co-fermentation [51]. In addition, the effects of residual hemicelluloses on enzymatic hydrolysis may be different [53], as reported by Ref. [54], who observed that the effect of residual hemicelluloses on the enzymatic hydrolysis was irrelevant compared to the effect of residual lignin on acid treated $\left(\mathrm{H}_{2} \mathrm{SO}_{4}\right)$ sorghum straw, alkaline solution $(\mathrm{NaOH})$ and acid $\left(\mathrm{H}_{2} \mathrm{SO}_{4}\right)$, followed by alkaline $(\mathrm{NaOH})$.

The analyzed hybrids presented similar cellulose content, besides not presenting significant difference between the environments. In a breeding program, the existence of genetic variation between individuals is strictly necessary, since it allows the identification of the most suitable genotypes according to the performance related to the desirable characteristics. This fact is verified for the hybrids of sorghum biomass used in this study, which presented significance for some of their evaluated characters, mainly in the possibility of identifying less recalcitrant materials, maximizing the production of monomeric carbohydrates from the structural carbohydrates, and, therefore, alternative for the production of economically efficient biofuels [62].

As the conventional hybrids presented higher lignin contents and the percentages of cellulose did not differ statistically among the genotypes, it is assumed that the $b m r$ hybrids of biomass sorghum are the most promising raw materials for obtaining ethanol of second generation [61,63-66]. These genotypes have high biomass yield with low lignin contents, ideal characteristics for the production of ethanol cellulosic. In addition, among the environments, as there was no difference in the mean content of DBY and cellulose, and it was verified difference for the lignin character, considering that Sete Lagoas was the environment where the harvest was later. It is inferred, therefore, that to obtain a material with technological characteristics more favorable to the production of $2 \mathrm{G}$ ethanol the harvest should be more precocious. New experiments will help to confirm the best cultivation time that will provide the best compositional quality for second-generation biofuels.

Estimates of productivity of ethanol with sorghum biomass, with high and satisfactory results, values the potential of this crop for the supply of biofuels. In addition, the supply of raw material in a maximum period of six months, being therefore much more efficient than sugarcane, which has a cycle of twelve to eighteen months.

The correlations between the variables are expressed in Table 3. The knowledge of the correlation estimates allows evaluating the degree of association between two characters. The estimates show positive or negative influence among the variables, predicting the behavior of others [55]. However, care must be taken in interpreting the magnitude of a correlation, since it is made affected by direction (of -1 a 1 , where the sign indicates the positive or negative direction of the relationship and the value suggests the strength of the relationship between the 
Table 3

Estimates of the Pearson phenotype correlation coefficients ( $\mathrm{rf} \mathrm{xy}$ ) between the traits: plant height (PH (m)), fresh biomass yield (\%), dry biomass yield (DBY Mg $\mathrm{ha}^{-1}$ ), acid detergent fiber (ADF\%), neutral detergent fiber (NDF), cellulose (\%), hemicellulose (\%), cultivated in Sete Lagoas and Couto Magalhães de Minas in the 2015/2016 season.

\begin{tabular}{|c|c|c|c|c|c|c|c|}
\hline Variable & FBY & DBY & $\mathrm{ADF}$ & $\mathrm{NDF}$ & Cellulose & Hemicellulose & Lignin \\
\hline $\mathrm{PH}$ & $0,37^{*}$ & $0,48^{* *}$ & $0,54 * *$ & $0,41 *$ & $0,42^{* *}$ & $-0,24$ & $0,60^{* *}$ \\
\hline FBY & & $0,93^{* *}$ & 0,06 & $-0,13$ & $-0,14$ & $-0,49 * *$ & $0,38^{*}$ \\
\hline DBY & & & 0,24 & 0,04 & 0,01 & $-0,47 * *$ & $0,56^{* *}$ \\
\hline $\mathrm{ADF}$ & & & & $0,91 * *$ & $0,94^{* *}$ & $-0,08$ & $0,86^{* * *}$ \\
\hline NDF & & & & & $0,96^{* *}$ & 0,32 & $0,64 * *$ \\
\hline Cellulose & & & & & & 0,15 & $0,65^{* *}$ \\
\hline Hemicelluose & & & & & & & $-0,44 *$ \\
\hline
\end{tabular}

variables), by the difference of importance of the characters, by the effect of two or more characters, and by the influence of the environment on their expression [56]. It is observed that there are positive and significant correlations between the agronomic characters and the technological variables of the evaluated genotypes (FBY x PH, DBY, hemicellulose, lignin, DBY $x$ PH, FBY, hemicellulose, lignin, cellulose $\mathrm{x}$ $\mathrm{PH}, \mathrm{ADF}, \mathrm{NDF}$, lignin; hemicellulose $\mathrm{x}$ lignin) suggesting that there is an association between the characters.

The highest values of significant and positive correlation were observed between FBY x DBY (0.93) and cellulose x NDF and ADF (0.96 and 0.94). It was also found that the characters lignin $x$ DBY (0.56), lignin $\mathrm{x}$ ADF (0.86), lignin $\mathrm{x}$ cellulose $(0.65)$ correlate positively and significantly. These results may be due to the sensitivity characteristic of the genotypes to the photoperiod, promoting an increase of the vegetative cycle and a greater accumulation of biomass, reflecting in the productivities of fresh and dry biomass and consecutively in the fiber contents.

\section{Conclusions}

The differences found between the experimental fields reinforce the existence of microclimatic variations that may occur among the specimens collected within different sections of the planted area. However, the variability detected in the tested genotypes allowed identifying the best materials in relation to the performance for the characters of interest.

The non-interaction between the environments and the genotypes, for all evaluated characters, made it possible to infer that there is no influence of the environment on the genotype, indicating stability of the genotypes. The high yield of the hybrids, coupled with better chemical characteristics, will aid in decision-making as to which materials are most conducive to the future development of second-generation biofuels.

The significant difference between genotypes is extremely important for selecting genotypes more suitable for energy conversion. Biomass sorghum hybrids are predominantly composed of structural carbohydrates (hemicellulose, cellulose and lignin) and their biomass can be used for second-generation biofuels. However, from the results obtained in this work, it is concluded that the "bmr" hybrids are the most promising for the optimization of saccharification processes and obtaining cellulosic ethanol.

\section{Declarations of interest}

None.

\section{Acknowledgments}

The authors would like to thank Embrapa Maize and Sorghum, for the support in conducting the experiment and for providing the germplasm, and BNDES for the financial support. This study was financed in part by the Brazilian Federal Agency for Support and Evaluation of
Graduate Education - Brazil (CAPES) - Finance Code 001.

\section{References}

[1] D. Khatiwada, S. Leduc, S. Silveira, I. Mccallum, Optimizing ethanol and bioelectricity production in sugarcane biorefineries in Brazil, Renew. Energy 85 (2016) 371-386 2016.

[2] J.G.G. Jonker, F.V.D. Hilst, H.M. Junginger, O. Cavalett, M.F. Chagas, A.P.C. Faaij, Outlook for ethanol production costs in Brazil up to 2030, for different biomass crops and industrial technologies, Appl. Energy 147 (2015) 593-610 2015.

[3] V. Scott, R.S. Haszeldine, S.F.B. Tett, A. Oschlies, Fossil fuels in a trillion tonne world, Nat. Clim. Chage 5 (2015) 419-423 2015.

[4] Conab, Safra 2015/16, nº1, Companhia Nacional de Abastecimento. Acompanhamento da safra brasileira de cana-de-açúcar vol. 2, Primeiro Levantamento, Brasília, 20172017.

[5] BP, Statistical Review of world energy, (2015) June, 2015. Disponível em: https:// www.bp.com/content/dam/bp/pdf/energy-economics/statistical-review-2015/bpstatistical-review-of-world-energy-2015-full-report.pdf.

[6] A. J. de H. Guevara, O.R. Silva, H.L. Hasegawa, D. Venanzi, Avaliação de Sustentabilidade da Produção de Ethanol no Brasil: Um Modelo em Dinâmica de Sistemas, BBR, Braz. Bus. Rev., Vitória 14 (4) (2017) 435-447 ago. 2017.

[7] REN21. Renewables, Global Status Report, REN21, Paris, 2017 2017. Available http://www.ren21.net/gsr-2017/.

[8] D. Nagaiah, P. Srinivasa Rao, R.S. Prakasham, A. Uma, K. Radhika, Y. Barve, A.V. Umakanth, High biomass sorghum as a potential raw material for biohydrogen production: a preliminar avaluation, Curr. Trends .Biotechnol. Pharm. Guntur 6 (2012) 183-189 2012.

[9] S.O. Serna-Saldívar, C. Chuckhernández, E. Pérez-Carrillo, E. Eredia-Olea, Sorghum as a Multifunctional Crop for the Production of Fuel Ethanol: Current Status and Future Trends, in: M.A.P. Lima (Ed.), Bioethanol, 2012 2012. Disponível em: http:// www.intechopen.com/books/bioethanol/sorghum-as-a-multifunctional-crop-fortheproduction-of-fuel-ethanol-current-statusand-future-trend.

[10] P.C. Magalhães, F.O.M. Durães, J.A.S. Rodrigues, Ecofisiologia, Cultivo do Sorgo Embrapa Milho e Sorgo, Sistema de produção versão eletrônica, $6^{\mathrm{a}}$ ed, 2010 Set./ 2010. Disponível em http://www.cnpms.embrapa.br/publicacoes/sorgo_6_ed/ ecofisiologia.htm.

[11] A. May, Documentos 152, Cultivo do sorgo biomassa para a cogeração de energia Elétrica. Embrapa Milho e Sorgo vol 65, Embrapa Milho e Sorgo, Sete Lagoas, 2013, p. 2013.

[12] M.A. Carrillo, S.A. Staggenborg, J.A. Pineda, Washing sorghum biomass with water to improve its quality for combustion, Fuel 116 (2014) 427-431 2014.

[13] Bndes, Corredor Bioceânico - Estudos de Demanda. Abril, 2011, (2011) Disponível em: http://www.bndes.gov.br.

[14] R. A. da C. Parrella, C. B. de Menezes, J.A.S. Rodrigues, F.D. Tardin, N.N.L.D. Parrella, R.E. Schaffert, Cultivares, in: A. Borém, L.D. Pimentel, R. A. da C. Parrella (Eds.), Sorgo: do plantio à colheita, vol. 7, UFV, Viçosa, MG, 2014, pp. 169-187 2014.

[15] T.P.S. Vendruscolo, M.A.A. Barelli, M.A.S. Castrillon, R.S. Silva, F.T. Oliveira, C.L. Corrêa, B.W. Zago, F.D. Tardin, Correlation and path analysis of biomass sorghum production, Genet. Mol. Res. 15 (4) (2016) 2016.

[16] S. Qiu, M.P. Yadav, L. Yin, Characterization and functionalities study of hemicellulose and cellulose components isolated from sorghum bran, bagasse and biomass, Food Chem. 230 (2017) 225-233 2017.

[17] W. Zegada-Lizarazu, A. Monti, Are we ready to cultivate sweet sorghum as a bioenergy feedstock? A review on field management practices, Biomass Bioenergy 40 (2012) 1-12 2012.

[18] Y.N. Guragaina, K.M. Ganesh, S. Bansal, R.S. Sathish, N. Rao, P.V. Vadlani, Lowlignin mutant biomass resources: Effect of compositional changes on ethanol yield, Ind. Crop. Prod. 61 (2014) 1-8 2014.

[19] S.E. Sattler, D.L. Funnell-Harris, J.F. Pedersen, Efficacy of singular and stacked brown midrib 6 and 12 in the modification of lignocellulose and grain chemistry, J. Agric. Food Chem. 58 (6) (2016) 3611-3616 2010a.

[20] A.L.S. Reis, E.D.D. Damilano, R.S.C. Menezes, M.A. Morais JR., Second-generation ethanol from sugarcane and sweet sorghum bagasses using the yeast Dekkera bruxellensis, Ind. Crop. Prod. 92 (2016) 255-262 2016.

[21] F.C. Santos, M.R.A. Filho, A.V. Resende, A.C. Oliveira, T.C. Gomes, M.S. Oliveira, Adubações nitrogenada e potássica no sorgo biomassa -produtividade e qualidade 
de fibra, Revista Brasileira de Milho e Sorgo 13 (1) (2014) 1-13 2014.

[22] J.F. Pedersen, K.P. Vogel, D.L. Funnell, Impact of reduced lignin on plant fitness, Crop Sci. 45 (2005) 812-819 2005.

[23] K.S. Porter, J.D. Axtell, V.L. Lechtenberg, V.F. Colenbrander, Phenotype, ber composition, and in vitro dry matter disappearance of chemically induced brown midrib (bmr) mutants of sorghum, Crop Sci. 18 (1978) 205-209 1978.

[24] C. Halpin, K. Holt, J. Chojecki, D. Oliver, B. Chabbert, B. Monties, K. Edwards, A. Barakate, G.A. Foxon, Brown-midrib maize $(b m r-1)$ : a mutation affecting the cinnamyl alcohol dehydrogenase gene, Plant J. v. 14 (1998) 545-553 1998.

[25] G.J. Provan, L. Scobbie, A. Chesson, Characterisation of lignin from CAD and OMT deficient Bm mutants of maize, J. Environ. Sci. Health B 73 (1997) 133-142 1997.

[26] S.E. Sattler, A.J. Saathoff, E.J. Haas, N.A. Palmer, D.L. Funnell-Harris, G. Sarath, J.F. Pedersen, A nonsense mutation in a cinnamyl alcohol dehydrogenase gene is responsible for the Sorghum brown midrib 6 phenotype, Plant Physiol. 150 (2009) 584-595 2009.

[27] A.L. Oliver, J.F. Pedersen, R.J. Grant, T.J. Klopfenstein, H.D. Jose, Comparative effects of the sorghum $b m r-6$ and $b m r-12$ genes: I. Forage sorghum yield and quality, Crop Sci. 45 (2005) 2234-2239 2005.

[28] A. Saballos, G. Ejeta, E. Sanchez, C. Kang, W. Vermerris, A genomewide analysis of the cinnamyl alcohol dehydrogenase family in Sorghum [Sorghum bicolor (L.) Moench] identifies SbCAD2 as the Brown midrib 6 gene, Genetics 181 (2009) 783-795 2009.

[29] S.E. Sattler, D.L. Funnell-Harris, J.F. Pedersen, Brown midrib mutations and their importance to the utilization of maize, sorghum, and pearl millet lignocellulosic tissues, Plant Sci. 178 (2010) 229-238 2010b.

[30] J.H. Cherney, D.J.R. Cherney, D.E. Akin, J.D. Axtell, Potential of brown-midrib, low-lignin mutants for improving forage quality, Adv. Agron. 46 (1991) 157-198 1991.

[31] J.B. Robertson, P.J. Van Soest, The detergent system of analysis and its application to humam foods, in: W.P.T. James, O. Theander (Eds.), The analysis of dietary fiber in food, Marcel Dekker, New York, 1981, pp. p123-158 1981.

[32] F.P. Gomes, C.H. Garcia, Statistics applied to agronomic and forest experiments, FEALQ, Piracicaba, 2002, p. 3092002.

[33] A.J. Scott, M. Knott, A cluster analysis method for grouping means in the analysis of variance, Biometrics, Raleigh 30 (3) (1974) 507-512 Sept.1974.

[34] C.D. Cruz, Genes, A Software Package for Analysis in Experimental Statistics and Quantitative Genetics, Acta Sci. Agron. 35 (3) (2013) 271-276 2013.

[35] M.A.P. Ramalho, B.L. Carvalho, J.A.R. Nunes, Perspectives for the use of quantitative genetics in breeding of autogamous plants, ISRN Genetics (2013), https://doi. org/10.5402/2013/718127 6 pages.

[36] F.M.R. Castro, A.T. Bruzi, J.A.R. Nunes, R.A.C. Parrela, G.M.R. Lombardi, C.J.B. Albuquerque, M. Lopes, Agronomic and energetic potential of biomass sorghum genotypes, Am. J. Plant Sci. 6 (2015) 2015.

[37] R.A.C. Parrella, Cultivares, in: A. May, D. D. da Silva, F. C. dos Santos (Eds.), Cultivo do sorgo biomassa para a cogeração de energia elétrica, Embrapa Milho e Sorgo, Sete Lagoas, 2013, p. 652013.

[38] C.A. Barcelos, R.N. Maeda, L.M.M. Santa Anna, N. PereiraJr, Sweet sorghum as a whole-crop feedstock for ethanol production, Biomass Bioenergy 94 (2016) 46-56 https://doi.org/10.1016/j.biombioe.2016.08.012.

[39] L.F. Souza, R.A.C. Parrella, C.V. Santos, V.F. Souza, N.N.L.D. Nádia Nardely Lacerda Durães Parrella, R.E. SCHAFFERT, Productive performance of biomass sorghum hybrids in different environments, XXXI NATIONAL CONGRESS OF MAIZE AND SORGHUM, "Milho e Sorgo: inovações, mercados e segurança alimentar", Bento Gonçalves/RS, 20162016.

[40] R.A.C. Parrella, R.E. Schaffert, A. May, B. Emygdio, A.F. Portugal, C.M.B. Damasceno, Agronomic performance of biomass sorghum hybrids. Research and Development Bulletin, n. 41 Embrapa Milho e Sorgo (Brazilian Agricultural Research Corporation), Sete Lagoas, 2011, p. 192011.

[41] R.A. Parrella, C. Cultivars, A. May, D. D. da Silva, F. C. dos Santos (Eds.), Cultivation of sorghum biomass for cogeneration of electric energy, Embrapa Milho e Sorgo (Brazilian Agricultural Research Corporation), Sete Lagoas, 2013, p. 652013.

[42] A. Borém, G.V. Miranda, Plant breeding, 5. ed, vol. 1, Publishing company UFV, Viçosa, 2009, p. 5292009.

[43] T. Van Der Weijde, A.F. Torres, O. Dolstra, A. Dechesne, R.G.F. Visser, L.M. Trindade, Impact of different lignin fractions on saccharification efficiency in diverse species of the bioenergy crop miscanthus, Bioenergy Res. 9 (2016) 146-156 2016.

[44] J. Ke, S. Chen, Thermal decomposition of lignin structural modification in termite digested softwood (II), Fuel 104 (2013) 781-787 2013.

[45] M.M.M. Vieira, W.J.E. Mochel Filho, Influência dos fatores abióticos no fluxo de biomassa e na estrutura do dossel, Arch. Zootec. 59 (2010) 15-24 2010.

[46] X. Zhao, F. Peng, K. Cheng, D. Liu, Enhancement of the enzymatic digestibility of sugarcane bagasse by alkali-peracetic acid pretreatment, Enzym. Microb. Technol. 44 (2009) 17-23 2009.

[47] L. Canilha, V.T.O. Santos, G.J.M. Rocha, J.B.M. Silva, M. Giulietti, A study on the pretreatment of a sugarcane bagasse sample with dilute sulfuric acid, J. Ind. Microbiol. Biotechnol. 38 (2011) 1467-1475 2011.

[48] J.K. Saini, R. Saini, L. Tewari, Lignocellulosic agriculture wastes as biomass feedstocks for second-generation bioethanol production: concepts and recent developments, Biotech 5 (2015) 337-353 2015.

[49] Z. Zhou, Y. You, F. Lei, P. Li, J. Jiang, L. Zhu, Enhancement of enzymatic hydrolysis of sugarcane bagasse by pretreatment combined green liquor and sulfite, Fuel 203 (2017) 707-714 2017.

[50] K. Kapoor, N. Garg, R.K. Diwan, L. Varshney, A.K. Tyagi, Study the effect of gamma radiation pretreatment of sugarcane bagasse on its physcio-chemical morphological and structural properties, Radiat. Phys. Chem. 141 (2017) 190-195 2017.

[51] M. Rastogi, S. Shrivastava, Recent advances in second generation bioethanol production: An insight to pretreatment, saccharification and fermentation processes, Renew. Sustain. Energy Rev. 80 (2017) 330-340 2017.

[52] H. Patel, D. Chapla, A. Shah, Bioconversion of pretreated sugarcane bagasse using enzymatic and acid followed by enzymatic hydrolysis approaches for bioethanol production, Renew. Energy 109 (2017) 323-331 2017.

[53] D.M. Carvalho, J.H. Queiroz, J.L. Colodette, Assessment of alkaline pretreatment for the production of bioethanol from eucalyptus, sugarcane bagasse and sugarcane straw, Ind. Crop. Prod. 94 (2016) 932-941 2016.

[54] W.S. Cardoso, G.P. Tavares, P.V. Queiroz, S.S. Mota, M.C.M. Kasuya, J.H. Queiroz, Use of sorghum straw (Sorghum bicolor) for second generation ethanol production: pretreatment and enzymatic hydrolysis, Quím. Nova 36 (5) (2013) 623-627 2013.

[55] R. Vencovsky, P. Barriga, Genética biométrica no melhoramento, SBG, Ribeirão Preto, 1992, p. 4961992.

[56] D.S. Falconer, T.F.C. Mackay, 4. ed, Introduction to quantitative genetics, Longman, Harlow, 1996 1996. 464 p.

[57] A. Saballos, W. Vermerris, L. Rivera, G. Ejeta, Allelic association, chemical characterization and saccharification properties of brown midrib mutants of sorghum (Sorghum bicolor (L.) Moench), BioEnergy Res. 1 (2008) 193-204.

[58] S.E. Sattler, A. Saballos, Z. Xin, D.L. Funnell-Harris, W. Vermerris, J.F. Pedersen, Characterization of Novel Sorghum brown midrib Mutants from an EMSMutagenized Population, G3: Genes|Genomes|Genetics 4 (2014) 2115-2124 2014.

[59] S. Gorthy, K. Mayandi, D. Faldu, M. Dalal, Molecular characterization of allelic variation in spontaneous brown midrib mutants of sorghum (Sorghum bicolor (L.) Moench), Mol. Breed. 31 (2013) 795-803 2013.

[60] E.D. Scully, T. Gries, D.L. Funnell-Harris, Z. Xin, F.A. Kovacs, W. Vermerris, S.E. Sattler, Characterization of novel Brown midrib 6 mutations affecting lignin biosynthesis in sorghum, J. Integr. Plant Biol. 58 (2016) 136-149 2016.

[61] B.S. Dien, G. Sarath, J.F. Pedersen, S.E. Sattler, H. Chen, D.L. Funnell-Harris, N.N. Nichols, M.A. Cotta, Improved sugar conversion and ethanol yield for forage sorghum (Sorghum bicolor L. Moench) lines with reduced lignin contents, BioEnergy Res. 2 (2009) 153-164 2009.

[62] B. Godin, N. Nagle, S. Sattler, R. Agneessens, J. Delcarte, E. Wolfrum, Improved sugar yields from biomass sorghum feedstocks: comparing low-lignin mutants and pretreatment chemistries, Biotechnol. Biofuels 9 (2016) 1-11 2016.

[63] J. Cotton, G. Burow, V. Acosta-Martinez, J. Moore-Kucera, Biomass and cellulosic ethanol production of forage sorghum under limited water conditions, Bioenergy Res. 6 (2013) 711-718 2013.

[64] N.N. Deshavath, M. Mohan, V.D. Veeranki, V.V. Goud, S.R. Pinnamaneni, T. Benarjee, Dilute acid pretreatment of sorghum biomass to maximize the hemicellulose hydrolysis with minimized levels of fermentative inhibitors for bioethanol production vol. 7, 3 Biotech, 20172017.

[65] N.N. Deshavath, S. Mahanta, V.V. Goud, V.V. Dasu, P.S. Rao, Chemical composition analysis of various genetically modified sorghum traits: Pretreatment process optimization and bioethanol production from hemicellulosic hydrolyzates without detoxification, J. Environ. Chem. Eng. 6 (2018) 5625-5634 2018.

[66] K. Theerarattananoon, X. Wu, S. Staggenborg, J. Propheter, R. Madl, D. Wang, Evaluation and characterization of sorghum biomass as feedstock for sugar production, Trans. ASABE 53 (2010) 509-525 2010.

[67] Y. Barrière, C. Riboulet, V. Méchin, S. Maltese, M. Pichon, A.J. Cardinal, C. Lapierre, T. Lubberstedt, J.P. Martinant, Genetics and genomics of lignification in grass cell walls based on maize as a model system, Genes, Genomes Genomics 1 (2007) 133-156 2007.

[68] A.K. Kumar, S. Sharma, Recent updates on different methods of pretreatment of lignocellulosic feedstocks: a review, Biores. Bioprocess. 4 (2017) 2017.

[69] P. Phitsuwan, K. Sakka, K. Ratanakhanokchai, Structural changes and enzymatic response of Napier grass (Pennisetum purpureum) stem induced by alkaline pretreatment, Biores. Tecnol. 218 (2016) 247-256 2016. 